\author{
M.T. Jenaliyev ${ }^{1}$, A.S. Kassymbekova ${ }^{2}$ \\ ${ }^{1}$ Institute of Mathematics and Mathematical Modeling CS MES RK, Almaty, Kazakhstan; \\ ${ }^{2}$ Al-Farabi Kazakh National University, Almaty, Kazakhstan \\ (E-mail: muvasharkhan@gmail.com)
}

\title{
On the boundary value problem for the loaded parabolic equations with irregular coefficients
}

\begin{abstract}
In the paper we consider the generalized solvability of boundary value problem for the loaded parabolic equations with irregular coefficients. Theorem on unique solvability of the boundary value problem is proved. The correctness of the theorem and the accuracy of selected functional spaces are established by obtained a priori estimates. The proof of the theorem is carried out using the theory of Sobolev spaces, the method of a priori estimates, and the Galerkin method. Along with the initial boundary value problem, the corresponding adjoint boundary value problem is investigated. To prove the solvability of the adjoint problem, we define a linear continuous form and use the duality relations.
\end{abstract}

Keywords: generalized solvability, boundary value problems, irregular coefficients, a priori estimates, unique solution.

\section{Introduction}

It is well-known that one of the central issues in the theory of boundary value problems for partial differential equations is the question on the correct choice of functional spaces. Boundary value problems for the loaded equations were studied systematically in $[1,2]$. The questions of existence and uniqueness of solutions of the loaded equations in the class of continuous functions were considered in $[1,2]$. In present work we develop these studies.

1 Statement of the of the boundary value problem

Suppose $\Omega \in R^{n}$ is bounded domain with boundary $\Gamma, Q=\Omega \times(0, T), \Sigma=\times(0, T), \Gamma$ is positioned locally on one side of the domain $\Omega$. We consider the following boundary value problem

$$
\begin{gathered}
D_{t}^{1} u=\sum_{i, j=1}^{n} D_{x_{i}}^{1}\left(a_{i j} D_{x_{j}}^{1} u\right)+ \\
+\sum_{i=1}^{p} \nu_{i}(t) \int_{\Gamma_{i}} e_{i}(x, \xi, t) u(\xi, t) d \xi+f=0 \text { on } Q ; \\
u(x, t)=0 \text { on } \Sigma ; \\
u(x, 0)=u_{0} \text { on } \Omega
\end{gathered}
$$

where $e_{i} \in L^{\infty}\left(0, T ; L^{4}\left(\Omega \times \Gamma_{i}\right)\right) ; \nu_{i}(t) \in L_{2}(0, T), i=1, \ldots, p, \Gamma_{i}$; are $(n-1)-$ dimensional manifolds from $\bar{\Omega}$, $n \leq 3$ (for $n=1, \Gamma_{i}$ are fixed points from $\left.\bar{\Omega}\right) ; \Gamma_{i}, i=1, \ldots, n$ together with $\Gamma$ from $C^{2} ; a_{i j} \in L^{\infty}\left(0, T ; C^{1}(\Omega)\right.$ ), $a_{i j}=a_{j i}, i, j=1, \ldots, p$ for almost every $\{x, t\} \in Q$ :

$$
\beta_{2} \sum_{i=1}^{n} \zeta_{i}^{2} \geq \sum_{i, j=1}^{n} a_{i j} \zeta_{i} \zeta_{j} \geq \beta_{1} \sum_{i=1}^{n} \zeta_{i}^{2},
$$

$\beta_{1}, \beta_{2}=$ const $>0, \forall \zeta \in R^{n}, f \in L^{2}(Q), u_{0} \in H_{0}^{1}(\Omega)$ 
2 The theorem of existence and uniqueness of the solution

For the boundary value problem (1)-(3) we obtain a priori estimates to ensure the correctness and accuracy of the selected function spaces.

Theorem 1. Let conditions (4) hold. Then the problem (1)-(3) has a unique solution $u \in Y(0, T)$ for all $f \in L^{2}(Q)$ and $u_{0} \in H_{0}^{1}(\Omega)$. Moreover, this solution continuously depends on the initial data, i.e. the map $\left\{f, u_{0}\right\} \rightarrow u$ of a direct product of the spaces $L^{2}(Q) \times H_{0}^{1}(\Omega)$ into the space $Y(0, T)$ is continuous, where

$$
Y(0, T)=\left\{u / u \in L^{2}\left(0, T ; H^{2}(\Omega) \cap H_{0}^{1}(\Omega)\right), \frac{\partial u}{\partial t} \in L^{2}(Q)\right\} .
$$

Proof. Now we take the inner product of equation (1) with $\Delta u$

$$
\begin{gathered}
\left(\frac{\partial u}{\partial t}, \Delta u\right)=\left(\sum_{i, j=1}^{n} \frac{\partial}{\partial x_{i}}\left(a_{i j} \frac{\partial u}{\partial x_{j}}\right), \Delta u\right)+ \\
+\left(\sum_{i=1}^{p} \nu_{i}(t) \int_{\Gamma_{i}} e_{i}(x, \xi, t) u(\xi, t) d \xi, \Delta u\right)+(f, \Delta u),
\end{gathered}
$$

where $(\varphi, \psi)=\int_{\Omega} \varphi \psi d x,\|\varphi\|=[(\varphi, \varphi)]^{\frac{1}{2}}, \Delta$ is Laplace operator.

Further, we use the following inequality [3]

$$
\left(\sum_{i, j=1}^{n} \frac{\partial}{\partial x_{i}}\left(a_{i j} \frac{\partial u}{\partial x_{j}}\right), \Delta u\right) \geq \frac{3 \beta_{1}}{4}\left\|u_{x x}\right\|^{2}-C_{1}\left\|u_{x}\right\|^{2}
$$

for a.e. $t \in[0, T]$ and $\forall u \in Y(0, T),\left|u_{x x}\right|=\left(\sum_{i, j=1}^{n} u_{x_{i}} u_{x_{j}}\right)^{\frac{1}{2}}, C_{1}>0$.

By inequality (6), equality (5) implies that

$$
\begin{gathered}
\frac{1}{2} \frac{d}{d t}\|u(t)\|_{H_{0}^{1}(\Omega)}^{2}+\frac{3 \beta_{1}}{4}\left\|u_{x x}\right\|^{2}-C_{1}\left\|u_{x}\right\|^{2} \leq \\
\leq \sum_{i=1}^{p}\left|\left(\nu_{i}(t) \int_{\Gamma_{i}} e_{i}(x, \xi, t) u(\xi, t) d \xi, \Delta u(t)\right)\right|+|(f, \Delta u)| .
\end{gathered}
$$

Applying the Hölder inequality [3], we estimate the first term of the right hand side of (7).

$$
\begin{gathered}
\sum_{i=1}^{p}\left|\left(\nu_{i}(t) \int_{\Gamma_{i}} e_{i}(x, \xi, t) u(\xi, t) d \xi, \Delta u\right)\right| \leq \\
\leq \sum_{i=1}^{p}\left|\nu_{i}(t)\right|\left\|e_{i}(t)\right\|_{L^{4}\left(\Omega \times \Gamma_{i}\right)} \sqrt[4]{\operatorname{meas} \Omega} \sqrt{\operatorname{meas} \Gamma_{i}} C_{i}\|u(t)\|_{H_{0(\Omega)}^{1}}\|\Delta u\|,
\end{gathered}
$$

where $C_{i}$ satisfies the following inequality

$$
\|u(t)\|_{L^{4}\left(\Gamma_{i}\right)} \leq C_{i}\|u(t)\|_{H_{0}^{1}(\Omega)}
$$

for a.e. $t \in(0, T), i=1, \ldots, p[4]$. 
Then the relation (7) implies

$$
\begin{gathered}
\frac{1}{2} \frac{d}{d t}\|u(t)\|_{H_{0}^{1}(\Omega)}^{2}+\frac{3 \beta_{1}}{4}\left\|u_{x x}\right\|^{2}-C_{1}\left\|u_{x}\right\|^{2} \leq \\
\leq C(t)\|u\|_{H_{0}^{1}(\Omega)}\|\Delta u\|+|(f, \Delta u)|,
\end{gathered}
$$

where $C(t)=\sum_{i=1}^{p}\left|\nu_{i}(t)\right|\left\|e_{i}(t)\right\|_{L^{4}\left(\Omega \times \Gamma_{i}\right)} C_{i} \sqrt[4]{\operatorname{meas} \Omega} \sqrt{\operatorname{meas} \Gamma_{i}}$

Further, by using the Cauchy inequality with $\varepsilon[3]$, we have

$$
\begin{gathered}
\frac{1}{2} \frac{d}{d t}\|u(t)\|_{H_{0}^{1}(\Omega)}^{2}+\frac{3 \beta_{1}}{4}\left\|u_{x x}(t)\right\|^{2}-C_{1}\left\|u_{x}(t)\right\|^{2} \leq \\
\leq \frac{C^{2}(t)}{2 \varepsilon_{1}}\|u(t)\|_{H_{0}^{1}(\Omega)}^{2}+\frac{\varepsilon_{1}}{2} C_{2}\left\|u_{x x}(t)\right\|^{2}+\frac{1}{2 \varepsilon_{2}}\|f(t)\|^{2}+\frac{\varepsilon_{2} C_{2}}{2}\left\|u_{x x}(t)\right\|^{2},
\end{gathered}
$$

where $C_{2}$ is a constant in $\|\Delta u(t)\| \leq \sqrt{C_{2}}\left\|u_{x x}(t)\right\|$. By choosing $\varepsilon_{1}, \varepsilon_{2}$ from conditions $\varepsilon_{1} C_{2}+\varepsilon_{2} C_{2} \leq \frac{\beta_{1}}{4}$, we have

$$
\begin{aligned}
& \frac{1}{2} \frac{d}{d t}\|u(t)\|_{H_{0}^{1}(\Omega)}^{2}+\frac{\beta_{1}}{2}\left\|u_{x x}(t)\right\|^{2} \leq \\
& \leq K_{1}(t)\|u(t)\|_{H_{0}^{1}(\Omega)}^{2}+\frac{1}{2 \varepsilon_{2}}\|f(t)\|^{2},
\end{aligned}
$$

where $K_{1}(t)=C_{1}+\frac{C^{2}(t)}{2 \varepsilon_{1}}$. Inequality (10) implies

$$
\frac{d}{d t}\|u(t)\|_{H_{0}^{1}(\Omega)}^{2} \leq K(t)\|u(t)\|_{H_{0}^{1}(\Omega)}^{2}+\frac{1}{\varepsilon_{2}}\|f(t)\|^{2},
$$

where $K(t)=2 C_{1}+\frac{C^{2}(t)}{\varepsilon_{1}}$.

Further, we use the Gronwall lemma [3]. Multiplying both sides of inequality (11) by $e^{-\int_{0}^{t} K(\tau) d \tau}$, we transfer the first term on the right hand side to the left hand side. So we obtain

$$
\frac{d}{d t}\left[\|u(t)\|_{H_{0}^{1}(\Omega)}^{2} e^{-\int_{0}^{t} K(\tau) d \tau}\right] \leq \frac{1}{\varepsilon_{2}}\|f(t)\|^{2} e^{-\int_{0}^{t} K(\tau) d \tau} .
$$

By integrating from 0 to $t$ and by exploiting the fact that $u(x, 0)=u_{0}$, we have

$$
\|u(t)\|_{H_{0}^{1}(\Omega)}^{2} \leq\left\|u_{0}\right\|_{H_{0}^{1}(\Omega)}^{2} \int^{\int_{0}^{t} K(\tau) d \tau}+\frac{1}{\varepsilon_{2}} \int_{0}^{t} e^{\int^{t} K(\tau) d \tau}\|f(\theta)\|^{2} d \theta
$$

Hence, it follows that

$$
\|u\|_{L^{\infty}\left(0, T ; H_{0}^{1}(\Omega)\right)}^{2} \leq \mathrm{const}\left(\left\|u_{0}\right\|_{H_{0}^{1}(\Omega)}^{2}+\int_{0}^{T}\|f(t)\|^{2} d t\right) .
$$

Substituting inequality (12) into the right hand side of inequality (10) by a standard way, we have

$$
\begin{gathered}
\|u\|_{L^{2}\left(0, T ; H^{2}(\Omega) \cap H_{0}^{1}(\Omega)\right) \cap L^{\infty}\left(0, T ; H_{0}^{1}(\Omega)\right)} \leq \\
\leq \mathrm{const}\left(\left\|u_{0}\right\|_{H_{0}^{1}(\Omega)}+\int_{0}^{T}\|f(t)\| d t\right) .
\end{gathered}
$$

By inequalities (12) and (13), and equation (1) and by

$$
\nu_{i}(t) \int_{\Gamma_{i}} e_{i}(x, \xi, t) u(\xi, t) d \xi \in L^{2}(Q),
$$


we obtain the following estimate

$$
\|u\|_{L^{2}\left(0, T ; H^{2}(\Omega) \cap H_{0}^{1}(\Omega)\right)} \leq K\left(\left\|u_{0}\right\|_{H_{0}^{1}(\Omega)}+\int_{0}^{T}\|f(t)\| d t\right) .
$$

For the further study we apply the Galerkin method. Let $w_{1}, w_{2}, \ldots, w_{N}, \ldots$, be a basis of the space $H^{2}(\Omega) \cap H_{0}^{1}(\Omega)$, i.e. the elements $w_{1}, w_{2}, \ldots, w_{N}$ are linear independent for all $N \in \mathbb{N}$; the set of linear combinations $\sum \xi_{j} w_{j}$ is dense in $H^{2}(\Omega) \cap H_{0}^{1}(\Omega)$ ( $\xi_{i}$ are constants).

We define the approximate solution of the problem (1)-(3) in the following form

$$
u_{N}(x, t)=\sum_{i=1}^{N} g_{i N}(t) w_{i}(x),
$$

where the functions $g_{i N}(t), i=1, \ldots, N$ are chosen such that the following relations hold

$$
\begin{gathered}
\left(\frac{\partial u_{N}}{\partial t}, w_{j}\right)+\sum_{i, j=1}^{n}\left(a_{i j} \frac{\partial u_{N}}{\partial x_{i}}, \frac{\partial w_{j}}{\partial x_{j}}\right)+ \\
+\sum_{i=1}^{p}\left(\nu_{i}(t) \int_{\Gamma_{i}} e_{i} u_{N} d \xi, w_{j}\right)=\left(f, w_{j}\right), \quad 1 \leq i \leq N,
\end{gathered}
$$

$u_{N}(x, 0)=u_{0 N}(x)=\sum_{i=1}^{n} \eta_{i N} w_{i}$, where $\left\{\eta_{i N}\right\}$ such that

$$
\sum_{i=1}^{n} \eta_{i N} w_{i} \rightarrow u_{0} \text { in } H_{0}^{1}(\Omega) \text { when } N \rightarrow \infty
$$

The relations $(16),(17)$ are the Cauchy problem for systems of linear differential equations for the functions $g_{i N}(t)$.

$$
W_{N} \frac{d g_{N}}{d t}+A_{N}(t) g_{N}=f_{N}, g_{N}(0)=\left\{\eta_{i N}\right\}
$$

where

$$
\begin{aligned}
& W_{N}=\left\|\left(w_{i}, w_{j}\right)\right\|, \quad A_{N}(t)=\| \sum_{i, j=1}^{n}\left(a_{i j} \frac{\partial w_{i}}{\partial x_{i}}, \frac{\partial w_{j}}{\partial x_{j}}\right)+ \\
& +\sum_{i=1}^{p}\left(\nu_{i}(t) \int_{\Gamma_{i}} e_{i}(x, \xi, t) w_{i}(\xi) d \xi, w_{j}\right) \| \text {; } \\
& g_{N}(t)=\left\{g_{i N}(t)\right\}, f_{N}=\left\{\left(f, w_{j}\right)\right\} .
\end{aligned}
$$

Since $W_{N}$ is Gramian matrix, and consequently $\operatorname{det} W_{N} \neq 0$, for the finite number $\forall N$, then the problem (16), (17) has an unique absolutely continuous solution.

We show, that if $N \rightarrow \infty$, then $u_{N} \rightarrow u$, and $u$ is the solution of the problem (1)-(3). Due to the fact that for the approximate solution $u_{N}(x, t)$ of the equation (15) for each $N$ has a priori estimate of the form (14), then from the bounded sequence $\left\{u_{N}(x, t)\right\}_{N=1}^{\infty}$ one can take out a subsequence $\left\{u_{\mu}(x, t)\right\}_{\mu=1}^{\infty}$ such that

$$
u_{\mu} \rightarrow z \text { weakly in } H^{2,1}(Q) \text {. }
$$

By theorem on traces and by lemma on linear continuous mapping of weakly convergent sequences [4], we have

$$
u_{\mu} \rightarrow z \text { weakly in } H^{\frac{3}{2}, \frac{3}{4}}\left(\Gamma_{i}(t) \times(0, T)\right) .
$$

The relation (19) implies that

$$
u_{\mu} \rightarrow z \text { stronger in } L^{2}\left(\Gamma_{i}(t) \times(0, T)\right) .
$$


Let now $j$ be arbitrary fixed number and $\mu>j$. Since the relation (15) holds for $N=\mu$, then multiplying it by function $\varphi(t) \in \Phi=\left\{\varphi / \varphi \in C^{1}[0, T], \varphi(T)=0\right\}$ and integrating from 0 to $\mathrm{T}$, we obtain

$$
\begin{aligned}
& \int_{0}^{T}\left[\left(\frac{\partial u_{N}}{\partial t}, \varphi w_{j}\right)+\sum_{i, j=1}^{n}\left(a_{i j} \frac{\partial u_{N}}{\partial x_{j}}, \varphi \frac{\partial w_{j}}{\partial x_{i}}\right)+\right. \\
& \left.+\sum_{i=1}^{p}\left(\nu_{i}(t) \int_{\Gamma_{i}} e_{i} u_{N} d \xi, \varphi w_{j}\right)-\left(f, \varphi w_{j}\right)\right] d t=0 .
\end{aligned}
$$

Then integrating by part, we have

$$
\begin{gathered}
\int_{0}^{T}\left[-\left(u_{N}, \frac{\partial \varphi w_{j}}{\partial t}\right)+\sum_{i, j=1}^{n}\left(a_{i j} \frac{\partial u_{N}}{\partial x_{j}}, \varphi \frac{\partial w_{j}}{\partial x_{i}}\right)+\right. \\
\left.+\sum_{i=1}^{p}\left(\nu_{i}(t) \int_{\Gamma_{i}} e_{i} u_{N} d \xi, \varphi w_{j}\right)-\left(f, \varphi w_{j}\right)\right] d t= \\
=-\left(u_{N}(x, 0), \varphi(0) w_{j}(x)\right), \forall i, j .
\end{gathered}
$$

We take as $\varphi \in D((0, T)) \subset \Phi$ the function that is infinitely differentiable and finite function. Then, by taking the limit as $\mu \rightarrow \infty$ (that is possible by relations (18), (20) we obtain

$$
\begin{gathered}
\int_{0}^{T}\left[-\left(z, \frac{\partial \varphi w_{j}}{\partial t}\right)+\sum_{i, j=1}^{n}\left(a_{i j} \frac{\partial z}{\partial x_{i}}, \varphi \frac{\partial w_{j}}{\partial x_{j}}\right)+\right. \\
\left.+\sum_{i=1}^{p}\left(\nu_{i}(t) \int_{\Gamma_{i}} e_{i} z d \xi, \varphi w_{i}\right)-\left(f, \varphi w_{j}\right)\right] d t=0, \forall j, \varphi \in D((0, T))
\end{gathered}
$$

and

$$
\begin{gathered}
\int_{0}^{T}\left[-\left(z, w_{j}\right) \varphi^{\prime}+\sum_{i, j=1}^{n}\left(a_{i j} \frac{\partial z}{\partial x_{j}}, \frac{\partial w_{j}}{\partial x_{i}}\right) \varphi+\right. \\
\left.+\sum_{i=1}^{p}\left(\nu_{i}(t) \int_{\Gamma_{i}} e_{i} z d \xi, w_{j}\right) \varphi-\left(f, w_{j}\right) \varphi\right] d t=0 .
\end{gathered}
$$

By definition of the Schwarzian derivative we have

$$
\begin{gathered}
\int_{0}^{T} \frac{\partial}{\partial z}\left[\left(z, w_{j}\right)+\sum_{i, j=1}^{n}\left(a_{i j} \frac{\partial z}{\partial x_{j}}, \frac{\partial w_{j}}{\partial x_{i}}\right)+\right. \\
\left.+\sum_{i=1}^{p}\left(\nu_{i}(t) \int_{\Gamma_{i}} e_{i} z d \xi, w_{j}\right)-\left(f, w_{j}\right)\right] \varphi(t) d t=0, \forall j, \varphi \in D((0, T)),
\end{gathered}
$$

where $\frac{\partial}{\partial t}\left(z, w_{j}\right) \in D^{\prime}((0, T))$.

It is well known that $(F, \varphi)=0$ for all $\varphi \in D((0, T)) \Leftrightarrow \quad F=0 \in D^{\prime}((0, T))$, consequently,

$$
\begin{gathered}
\left(\frac{\partial z}{\partial t}, w_{j}\right)+\sum_{i, j=1}^{n}\left(a_{i j} \frac{\partial z}{\partial x_{j}}, \frac{\partial w_{j}}{\partial x_{i}}\right)+ \\
+\sum_{i=1}^{p}\left(\nu_{i}(t) \int_{\Gamma_{i}} e_{i} z(\xi, t) d \xi, w_{j}\right)=\left(f, w_{j}\right) .
\end{gathered}
$$


Further, since $j$ is arbitrary, and the set of linear combinations of elements $w_{1}, w_{2}, \ldots, w_{N}, \ldots$ is dense in $H^{2}(\Omega) \cap H_{0}^{1}(\Omega)$. Then the relation (23) implies that

$$
\frac{\partial z}{\partial t}+\sum_{i, j=1}^{n} \frac{\partial}{\partial x_{i}}\left(a_{i j} \frac{\partial z}{\partial x_{j}}\right)+\sum_{i=1}^{p} \nu_{i}(t) \int_{\Gamma_{i}} e_{i} z(\xi, t) d \xi=f
$$

Hence $\frac{\partial z}{\partial t} \in L^{2}(Q)$, thus $z \in Y(0, T)$.

For final derivation one can examine as $z$ satisfies the initial conditions. We take $\varphi \in \Phi$ such, that it is not necessary to be the finite function. Then as $N \rightarrow \infty$ we have

$$
\begin{gathered}
\int_{0}^{T}\left[-\left(z, \frac{\partial \varphi w_{j}}{\partial t}\right)+\sum_{i, j=1}^{n}\left(a_{i j} \frac{\partial z}{\partial x_{j}}, \varphi \frac{\partial w_{j}}{\partial x_{i}}\right)+\right. \\
\left.+\sum_{i=1}^{p}\left(\nu_{i}(t) \int_{\Gamma_{i}} e_{i} z(\xi, t) d \xi, \varphi w_{j}\right)-\left(f, \varphi w_{j}\right)\right] d t= \\
=-\left(u_{0}(x), \varphi(0) w_{j}(x)\right), \forall j \text { and for } \varphi \in \Phi .
\end{gathered}
$$

Integrating by part the relation (25), we have

$$
\begin{aligned}
& \int_{0}^{T}\left[\left(\frac{\partial z}{\partial t}+\sum_{i, j=1}^{n} \frac{\partial}{\partial x_{i}}\left(a_{i j} \frac{\partial z}{\partial x_{j}}\right)+\right.\right. \\
+ & \left.\left.\sum_{i=1}^{p} \nu_{i}(t) \int_{\Gamma_{i}} e_{i} z(\xi, t) d \xi, \omega_{j}-f\right) \varphi(t)\right]= \\
= & -\left(u_{0}(x), w_{j}\right) \varphi(0)-\left(z(x, 0), w_{j}\right) \varphi(0) .
\end{aligned}
$$

By $(24)$, we have $-\left(u_{0}(x), w_{j}\right)-\left(z(x, 0), w_{j}\right)=0, \forall j$. Consequently, namely $u_{0}(x)=z(x, 0)$ is the solution of the boundary value problem (1)-(3). The proof of theorem 1 is complete.

\section{The adjoint problem}

Let

$$
r \in Y_{0}^{\prime}, Y_{0}=\{u / u \in Y(0, T), u(x, 0)=0\}, p_{1} \in H^{-1}(\Omega)
$$

We consider the problem that is adjoint of the problem (1)-(3)

$$
\begin{gathered}
D_{t}^{1} p+\sum_{i, j=1}^{n} D_{x_{j}}^{1}\left(a_{i j} D_{x_{i}}^{1} p\right)+ \\
+\sum_{i=1}^{p} \nu_{i}(t) \delta\left(x-\Gamma_{i}\right) \int_{\Omega} e_{i}(\xi, x, t) p(\xi, t) d \xi=r(x, t) \text { on } Q ; \\
p(x, t)=0 \text { on } \Sigma, \\
p(x, T)=p_{1},
\end{gathered}
$$

where $\delta\left(x-\Gamma_{i}\right)$ - is the Dirac function. In order to prove solvability of the problem (27)-(29) we use the schema 2 from [4].

Under the condition of theorem 1 and by $\nu_{i}(t) \in L_{2}(0, T)$ the following operator

$$
u \rightarrow \frac{\partial u}{\partial t}-\sum_{i, j=1}^{n} \frac{\partial}{\partial x_{i}}\left(a_{i j} \frac{\partial u}{\partial x_{j}}\right)-\sum_{i=1}^{p} \nu_{i}(t) \int_{\Gamma_{i}} e_{i} u(\xi, t) d \xi
$$


corresponding to the problem (1)-(3) defines the homomorphism $Y(0, T) \rightarrow L^{2}(Q)[5]$. Consequently, if $\sigma(u)$ is linear continuous form above $Y(0, T)$, then by Riesz theorem [3] there exists an unique element $p(\nu) \in L^{2}(Q)$, such that $\forall u \in Y_{0}$

$$
\left(p(\nu), \frac{\partial u}{\partial t}-\sum_{i, j=1}^{n} \frac{\partial}{\partial x_{i}}\left(a_{i j} \frac{\partial u}{\partial x_{j}}\right)-\sum_{i=1}^{p} \nu_{i}(t) \int_{\Gamma_{i}} e_{i} u(\xi, t) d \xi\right)=\sigma(u)
$$

We define the following linear continuous form

$$
\sigma(u)=\left\langle\langle r(x, t), u(x, t\rangle\rangle+\left\langle p_{1}, u(x, T)\right\rangle,\right.
$$

where $\langle\langle.,\rangle$.$\rangle and \langle.,$.$\rangle are duality relations between spaces Y_{0}^{\prime}$ and $Y_{0}, H^{-1}(\Omega)$ and $H_{0}^{1}(\Omega)$, respectively.

Thus we state the following intermediate result.

Theorem 2. The problem (27)-(29) has unique solution $p(x, t) \in L^{2}(Q)$, that satisfies the integral identity (30)-(31) for all $\left\{r, p_{1}\right\}$, satisfying (26).

Let us give some of possible descriptions of the elements $r(x, t) \in Y_{0}^{\prime}$. We have

$$
\begin{gathered}
r(x, t)=r_{0}(x, t)+\frac{d}{d t}\left(\rho(t), r_{1}(x, t)\right) ; \\
r_{0}(x, t) \in L^{2}\left(0, T ;\left(H^{2}(\Omega) \cap H_{0}^{1}(\Omega)\right)^{\prime}\right), r_{1} \in L^{2}(Q),
\end{gathered}
$$

where $\rho(t)$ is infinitely differentiable function, defined, for example, by the following way $\left(0<t_{0}<\frac{1}{2}\right.$, $t_{0}$ is fixed):

$$
\rho(t)= \begin{cases}t, & 0 \leq t \leq t_{0} \\ \text { arbitrary, } & t_{0} \leq t \leq T-t_{0} \\ T-t, & T-t_{0} \leq t \leq T .\end{cases}
$$

Indeed, the estimates, that analogous with the estimates (12)-(14), hold for boundary value problem (27)-(29). And the following more stronger result is true. Let $r=0$, we state

Theorem 3. Let condition (4) hold. Then the problem (27)-(29) has unique solution $p \in Y(0, T)$ for all $p_{1} \in H_{0}^{1}(\Omega)$. This solution continuously depends on initial data, i.e. the map of the space $H_{0}^{1}(\Omega)$ into $Y(0, T)$ is continuous.

The proof of theorem 3 is similar with the proof of theorem 1.

Brief abstract of this work has been published in the Materials of the workshop «Differential operators and modeling of complex systems»(April 7-8, 2017, Almaty, Kazakhstan) [6].

Acknowledgements

This study is supported by grants No. AP05130928, AP05132262.

\section{References}

1 Nahushev A.M. Loaded equations and applications / A.M.Nahushev // Differential Equations. - 1983. - Vol. 19. - No. 1. - P. 86-94.

2 Нахушев А.М. Нагруженные уравнения и их применения / А.М.Нахушев. - М.: Наука, 2012.

3 Ладыженская О.А. Линейные и квазилинейные уравнения параболического типа / О.А.Ладыженская, В.А.Солонников, Н.Н.Уральцева. - М.: Наука, 1967.

4 Lions J.-L. Problemes aux limites nonhomogenes et applications / J.-L.Lions, E.Magenes. Vol. 1. Dunod, Paris, 2007.

5 Колмогоров, А.Н. Элементы теории функций и функционального анализа / А.Н.Колмогоров, С.В.Фомин. - М.: Наука, 1989. - С. 572.

6 Jenaliyev M.T. On the boundary value problem for the loaded parabolic equations with irregular coefficients / M.T.Jenaliyev, A.S.Kassymbekova // Kazakh Mathematical Journal. — 2017. — 17. — No. 1. — P. 107. 


\title{
М.Т. Жиеналиев, А.С. Қасымбекова
}

\section{Регулярлы емес коэффициентті жүктелген параболалық теңдеулер үшін бір шеттік есеп жайында}

\begin{abstract}
Мақалада регулярлы емес коэффициенттері бар жүктелген параболалық теңдеулер үшін шекаралық есептің жалпыланған шешімділігі қарастырылды. Шекаралық есептердің бірегей шешілетіндігі тұралы теорема дәлелденді. Теореманың дұрыстығы және таңдалған функционалдық кеңістіктердің дәлдігі алынған априорлы бағалаулармен анықталды. Теореманы дәлелдеу Соболев кеңістігінің теориясын, априорлы бағалау әдісін және Галеркин әдісін қолдана отырып жүзеге асырылды. Бастапқы шекаралық есеппен қатар, сәйкес түйіндес шекаралық есеп зерттелді. Түйіндес есептің шешімділігін дәлелдеу үшін сызықты үзіліссіз форма анықталды және түйіндестік қатынастар қолданылды.
\end{abstract}

Kiлm сөздер: жалпыланған шешімділік, шекаралық есептер, регулярлы емес коэффициенттер, априорлы бағалаулар, жалғыз шешім.

\section{М.Т. Дженалиев, А.С. Касымбекова}

\section{Об одной краевой задаче для нагруженных параболических уравнений с нерегулярными коэффициентами}

\begin{abstract}
В статье рассмотрена обобщенная разрешимость краевой задачи для нагруженных параболических уравнений с нерегулярными коэффициентами. Доказана теорема о единственной разрешимости краевой задачи. Корректность теоремы и точность выбранных функциональных пространств определены полученными априорными оценками. Доказательство теоремы проводится с использованием теории пространств Соболева, метода априорных оценок и метода Галеркина. Наряду с исходной краевой задачей исследуется соответствующая ей сопряженная краевая задача. Для доказательства разрешимости сопряженной задачи задается линейная непрерывная форма и используются соотношения двойственности.
\end{abstract}

Ключевые слова: обобщенная разрешимость, краевые задачи, нерегулярные коэффициенты, априорные оценки, единственное решение.

\section{References}

1 Nahushev, A.M. (1983). Loaded equations and applications. Differential Equations, 19, 1, 86-94.

2 Nahushev, A.M. (2012). Nahruzhennye uravneniia $i$ ikh primeneniia [Loaded equations and their applications]. Moscow: Nauka [in Russian].

3 Ladyzenskaia, O.A., Solonnikov, V.A., \& Ural'ceva, N.N. (1967). Lineinye i kvazilineinye uravneniia parabolicheskoho tipa [Linear and quasi-linear equations of parabolic type]. Moscow: Nauka [in Russian].

4 Lions, J.-L., \& Magenes, E. (2007). Problemes aux limites nonhomogenes et applications. Vol. 1. Dunod, Paris.

5 Kolmogorov, A.N., \& Fomin, S.V. (1989). Elementy teorii funktsii i funktsionalnoho analiza [Elements of the function theory and functional analysis]. Moscow: Nauka [in Russian].

6 Jenaliyev, M.T., \& Kassymbekova, A.S. (2017). On the boundary value problem for the loaded parabolic equations with irregular coefficients. Kazakh Mathematical Journal, 17, 1, 107. 